Article

\title{
Characteristics of Extraordinary Religious Phenomena Accompanying the Christian Religious Experience-Reflection
}

\section{Stanisław Glaz}

Jesuit Academy Ignatianum in Kraków, Kopernika Street 26, Poland; E-Mail: zjglaz@cyf-kr.edu.pl;

Tel.: +48-12-428-7895

External Editor: Peter Kaufman

Received: 23 October 2014; in revise form: 24 November 2014 / Accepted: 1 December 2014 /

Published: 9 December 2014

\begin{abstract}
This paper presents an attempt to discuss in more detail the question of understanding of religious experience in the context of the Christian religion, as well as to show the characteristic extraordinary religious experiences accompanying many people during that experience. The question of experiences evoked by psychedelic drugs, such as the issue of a vision and chemical ecstasy, are not discussed here, and instead the author has chosen to present only typical phenomena accompanying religious experience, which are caused by God's doing, like visions, ecstasy, glossolalia (speaking in tongues) or stigmata. The paper also presents their role and contribution to the process of a human being's religious development.
\end{abstract}

Keywords: Church; religious experience; religions relationship; religious phenomena; ecstasy; glossolalia; stigmata; visions

\section{Introduction}

During a religious experience, a human being can be accompanied by various religious phenomena, which some researchers describe as "incidental" religious phenomena. They are characterized by varied intensity, complexity and changeable frequency [1,2]. They can be visions, ecstasies, mystical raptures, and stigmata. These phenomena reveal considerable similarity both in the diachronic and transcultural dimension; they show certain transcultural, transreligious and transhistorical similarities. This kind of religious phenomena are often accompanied by the following facts: ecstatic balancing and swinging, ecstatic death, levitations, clairvoyance, and/or healing [2,3]. 
When analyzing a religious phenomenon, three development phases can be distinguished [4,5]. It often begins with a moderate exaltation phase; it is visible for example during evangelic meetings of charismatic character (glossolalia). Then it changes into the proper phase; it is a mystical form focused only on uniting man with God, a deity. It often ends in ecstasy, which occasionally is characterized by loss of consciousness of the person experiencing that state.

It was the university students of the Ignatianum Science Club that encouraged me to present the problem of extraordinary religious phenomena related to religious experience. Nowadays, it is noticeable that especially young people depart from the dimension of institutional religiosity in favor of an increased interest in personal religiosity [6,7]. Contemporary youth are more interested in the element of experience in religiosity, they pay considerable attention to religious phenomena. It can sometimes be observed that they identify experiences induced by psychedelic substances (boundary experiences) [8,9] or by stimulating the brain activity with the help of external tools (neurotheology) with religious experience caused by God [10]. Some researchers believe that visions, dreams, flights of soul, mystical moments play a significant, if not crucial role in mediating notions of the sacred in man's reality. Others have suggested that such phenomena do not bring anything good in human life, on the contrary, their source have disturbed personality [11,12]. It should be added that studies based on reviews, theoretical literature have indicated that extraordinary religious phenomena and psychotic-spectrum experience reveal some characteristics similar as well as different [13,14]. A question arises, on the one hand, whether it makes sense to write about religious experiences in the light of the visible major restraint and mistrust towards these phenomena amongst certain researchers [15], but, on the other hand, there is a vast interest in these phenomena among believers themselves. It seems advisable, then, to show the functions of religious phenomena and their meaning in a human being's spiritual life. Few scholars present the co-occurrence of religious phenomena and sometimes breakdowns and mental-spiritual overload in human life, which, in consequence, often lead to a serious life re-orientation [16]. In my opinion, Nowak ([17], p. 174) did justice when describing this problem. "Great ecclesiastical mystics, despite their incredible experiences of blissful or painful ecstasies, visions, up to stigmata, were people who worked well in social life, had the courage to live in accordance with their vocation, participated in social life. The strong integration with Christ intensified their true love for fellowmen, the spirit of sacrifice and selfless help. Their experiences contributed to accelerated personality development. All this would not have been possible had their experiences had a psychotic background." How does it compare with the teachings of the church about religious phenomena? In the Dogmatic Constitution on the Church ([18], para. 12) we read: "These charisms, whether they be the more outstanding or the more simple and widely diffused, are to be received with thanksgiving and consolation for they are perfectly suited to and useful for the needs of the Church. Extraordinary gifts are not to be sought after, nor are the fruits of apostolic labor to be presumptuously expected from their use; but judgment as to their genuinity and proper use belongs to those who are appointed leaders in the Church, to whose special competence it belongs, not indeed to extinguish the Spirit, but to test all things and hold fast to that which is good."

Referring to the materials relating to religious experience of people involved in the development of their own spiritual lives one can identify certain characteristic features of the extraordinary religious experiences accompanying those people. In the present paper I shall omit the problem of experiences induced by psychedelic substances, e.g., the question of chemical vision and ecstasy, and I will 
indicate only characteristic phenomena, such as vision, ecstasy, glossolalia, stigmata, accompanying religious experience and which occur within the Christian religion and are caused by God's activity [19]. I will also present their role and contribution to the process of a human being's religious and personality development.

\subsection{The Understanding of the Term "Religious Experience"}

The term "experience" is ambiguous and it refers to a person's cognitive activity [20]. In reference to religious issues, it denotes a certain process of direct acquisition of information about the religious reality [5,21]. According to James [22], religious experience is so special, specific that it is difficult to bring it down to any experience known to a human being; it being so unique and distinct makes it incomparable to any other human experience. Otto [23] claims that religious experience is a specific feeling of mystery that is fascinating and disturbing at the same time; it is possible thanks to the specific cognitive power-sensus numinis. This experience occurs in the direct internal feeling of Sacrum in human life. It is a process of affective-intellectual character.

In Unger's view [24], religious experience has never stopped to fascinate people. It is extraordinary and valuable for a human being and the society in which he or she lives. Jung [25] sees religious experience as the most wonderful quality of one's life, which can be shared by everyone. On the one hand, religious experience helps to take a fresh look at oneself, another person, and the world [26]; it assists in establishing deeper relationships with other individuals [27]; it provides new contents [23]; and it makes a person more creative [28]; but, on the other hand, as claimed by Freud [29,30] and others [31], this kind of experiences and related to them phenomena do not bring anything valuable to human life, but quite the contrary - they are illusions and often lead to neurotic disorders.

In Christian theology religious experience is understood as a direct capture of the presence of Divine reality, as a direct contact with God personified [5,32]. What predominates in it is the emotional-volitive dimension [33]. The essence of religious experience includes a human being's bond with God [34]. Gruehn [4] calls it "an immanent experience of transcendental God". A human being is the receiver of God's activity [35]. Religious experience is closely connected to man, who is often overcome, filled with it, and even at times deprived of logical thinking by it $[23,36]$.

Religious experience-similarly to occurring religious phenomena-presents a particularly difficult problem for scientific analysis. According to researchers the difficulty has a mainly methodological and theoretical character and can be divided into two groups [37]. These are methodological-epistemological difficulties, determined by the scientific status of theology, and methodological-theoretical difficulties, related to the status of the notion of religiosity and religious experience. The latter group of problems is much more serious and refers directly the issues of defining and assessment of religious phenomena [38]. It turns out, namely, that the variety of religious experiences is also enriched by their miscellaneous forms connected to the religious tradition in which they originate and the culture in which they are revealed [16,39].

Religious experience is marked by an existence of certain phases [4,32]. The first stage is man's contact with God. The activity lies often on God's part, which by revealing himself, communicates himself to man and passes on to him certain religious contents. The human being is the receiver and remains passive. In the second phase of religious experience a human being intuitively feels God's 
presence and involves him personally. He feels the desire to enter an interpersonal relationship with God. The ultimate aim of the personal contact with God is not only an attitude of respect and worship, but a desire and endeavor to be unified with Him. In the third phase the realized bond with God is actualized, which happens by an action (religious act), which is expressed in prayer, adoration of an individual $[24,36]$.

\subsection{The Components of the Christian Religious Experience}

Based on the related literature it can be noticed that researchers understand religious experience in various ways and that it can occur in different religious and cultures $[24,40]$. In the present article I focus on religious experience within the Christian religion. This kind of experience consists of: theological virtues - faith, hope, love - which enable a human being to have contact with God; God personified, who revealed himself in Jesus Christ and offers Himself to man [41]; a human being who has a reference to themselves, other people and to God [42]; a personal relationship which takes place between God and man during religious experience [31,43].

The Bible shows us God as the Creator of mankind and who looks after them (Genesis 1:5-25). He is transcendental in relation to history and events and simultaneously close to man. He is the living and true God, grace giver (Deuteronomy 5:1-32). He is the one and only God in the Holy Trinity [41]. His mystery is fulfilled through His becoming incarnate in Jesus Christ. The Son of God incarnated in the human form of Jesus Christ in order to redeem mankind, beloved in His human nature in the moment of Resurrection, present in the community of God's People (Acts 1:8), who are His Mystical Body, He brought justification to mankind (Acts 5:30-32) and let them partake of eternal life [44]. Man, in turn, who is created in the image of God, thanks to being raised by God to the supernatural state became the adopted Son of God and can partake of God's glory and salvation. Through being unified with God man participates in the inner Trinitarian life of God, which means in the personal relations between God the Father, God the Son and God the Holy Spirit (1 Peter 2:1-10). Man participates in the friendship with God and people [41,43].

In a religious relation that has a personal character, a human being accomplishes the most important aims of their existence [45]. He or she realizes himself or herself as a human being, participates in the Divine life, in holiness. The bond between man and God is formed through performing religious acts [35]. A religious act is man's primeval, automatic equipment. He is affirmed in relation to "something", an intentional object (God). The impossibility of fulfilling the intention of human act through good, human perfection proves its authentic religious character. The Supreme Good (God) is its fulfillment. A religious relationship reveals several specific features. It has an existential character, which means it is a true bond between man and God, and it encompasses the whole man. It has an intersubjective dimension - the relationship, which takes place between God and man is interchangeable [41,46]. It has a dynamic character, that is it refers to the complete, limitless involvement of God and man, and it is reciprocal, which means that man receives an answer from God $[32,47]$. 


\section{Specific Phenomena of the Christian Religious Experience}

When analyzing the spiritual lives of remarkable people one must admit that there exist certain stages typical of one's internal life [32,40]. It refers to e.g., its nature, development, signs, course and intensity. What ought to be mentioned in this context are the so-called religious phenomena, supernatural phenomena, occurring during religious experience, including the mystical one [48]. In order to better understand their origin, course and meaning in the development of man's spiritual life, I shall attempt to show it.

\subsection{Visions}

Visions, personal observation and seizing one's internal phenomena, dream visions, are image sensations with a long-term effect and take place with no recognizable contribution of external sensory perception. They often accompany ecstasy or mystical revelation [49]. During a vision, a person finds himself or herself in an altered state of consciousness, which differs from pathological states experienced in delirium. Supernatural visions are possible because God manages the natural rights of His creation in a free way. Such visions are frequently mentioned in the Bible, for example, the vision of Elijah (1 Kings 19:3-14) or the vision of St John (Re 7:1-17). God, by affecting the spiritual center of a human being, can bear witness to Himself and realities exceeding the limits of experience in a way that is comprehensible for human sensory perception [32,42].

Visions are understood as a person's perceiving certain people and objects, which are inaccessible for normal sight. Here is what Cardinal Ratzinger ([50], p. 47), great theologian, has to say about this. "It is obvious that in the case of the vision of Lourdes, Fatima, etc. we do not deal with ordinary external sensory perception. The images and persons, which were seen in them are not external elements of space, like for instance a tree or a house. It is totally evident for example in reference to the vision of Hell (described in the first secret of Fatima) or to the vision included in the third secret of Fatima, yet the same can be easily shown also in the case of other visions, mostly because they were not seen by all the people present but only the ones who were having the vision. It is also obvious that they are not image-less spiritual 'visions', which can be encountered on higher levels of religious experiences. Hence they belong to the middle category of internal perception, which undoubtedly has the power of actualisation for the one who has a vision, so that for him or her the vision equals an external phenomenon perceived with the senses."

Researchers analyzing religious phenomena also discerned several kinds of vision [5,51]. (They suggest that there are many kinds of vision). Firstly, visions of the first degree occur when the cognitive process takes place in a person's internal senses like sight, hearing, touch, and which consist in recognizing divine persons in the natural form (similar to human - authentic - material visions) or forged (a figure that seems to have been made of other material—pseudo-bodily visions). Visions of the second degree are when the cognitive process takes place in human imagination. They are characterized by perceiving not the body of the person seen in a vision, but the silhouette. This kind of vision is most often accompanied by an ineffable state of enlightenment and a feeling of possessing extraordinary abilities. In the case of visions of the third degree, in turn, the cognitive process takes 
place in a person's intellect. They are the basis of the true mysticism, are deprived of any sensory or imaginary experiences (such a negative term is the closest to the truth).

According to scientists, authentic visions do not show a fantasy character [5,52]. They are a true way of perception and understanding of reality and are related to one's ability to relax, which enables man's proper functioning [49]: Internal seeing does not mean that we deal with a figment of one's imagination, which is solely an expression of subjective imagination. It rather means that the soul comes into contact with something real, although extra-sensory, and it acquires the ability to see the invisible, imperceptible for the senses - to perceive with "internal senses". The soul comes here into contact with real "things", although they do not belong to the world of the senses that we are accustomed to. What is needed is inner vigilance of the heart, which a person usually lacks because of an excessive impact of external reality and the images and thoughts filling the mind. The person who has a vision is lead outside the pure externity and encounters deeper dimensions of reality, which become perceptible for him or her. Perhaps it explains why it is children who are the privileged recipients of such revelations: their minds are still not too misshapen, their inner ability of perception has not been excessively depleted [50]. "From the lips of children and infants you, Lord, have called forth your praise"-replies Jesus in the words of a psalm (Psalm 8:3) to the accusations of the chief priests and the teachers of the law who were indignant at children shouting hosanna! (Matthew 21:16).

\subsection{Ecstasy}

Ecstasy is seen as a kind of state of total or partial suspension of human consciousness in a given moment, which consists in making one's cognitive talents insensitive to some natural cognitive stimuli [53]. Its causes can be natural, diabolic, or supernatural [54,55]. Natural ecstasy is often linked with using psychedelic substances, techniques manipulating the human psyche. Diabolic ecstasy takes place when the Devil influences one's sensory sphere and triggers the appearance of any kind of images and stimulates to do apparent good. Supernatural ecstasy, in turn, occurs in the prophetic and mystical form (grace given for free). It is not only the fruit of a person's spiritual development. In mystical ecstasy God's activity is important, God's offering Himself to man; it is like being outside of oneself. It is connected with meditation and mystical life [56]. It is about entering an exceptional state of intense spiritual and emotional movement, whose forms are revealed and distinguished by varied duration and intensity. Ecstasy can overcome a person suddenly and without his or her active participation. All human spheres are involved in it, especially the emotional sphere [57]. One can notice exhaustion, diverse sensory reactions, especially the senses of hearing, touch, sight, and also the speech organs, which shows in the form of exclamation or sighing. Visions, which appear during ecstasy, seem to be more real and authentic than experiences of the senses, they are usually described by mystics in the language of notions of love and cannot be expressed in a discursive language. The common characteristics of ecstasy among given people are: suspension of a person's normal consciousness (the stilling of consciousness), as well as, to a smaller or greater extent, of the sense organs $[58,59]$. It happens due to man's excessive concentration on objects related to his religious life and his longing for the soul to be unified with God.

A person in ecstasy often exhibits a suspension of normal consciousness and a certain limitation of the functions of the sense organs as a result of immense concentration on God. A unification of man's 
soul with God takes place, the so-called immersion of the soul in God, sinking of the soul in God. Great mystics, like St Ignatius of Loyola [56,60] and St John of the Cross [61], describe this human state as love ecstasy. The soul surrendered to God's activity feels an internal reawakening and the creative presence of God. This person is accompanied by characteristic emotionality, God's presence in man's soul creates divine movement [52].

Ecstasy causes certain changes in a human being, which can be noticed in their life. Cataleptic signs are visible. They refer to rigidity of the body in a state of ecstatic rapture as well as calf cramps and convulsions. They can also involve changes in bodily functions, related to blood circulation, breathing, secretion [62]. Płużek [63] distinguished the characteristics of the symptoms of ecstasy. These include: exaltation of feelings on the one hand or their total calming, excessive vigilance of awareness or a state of dimmed awareness, lack of or reduced reactions to the surrounding world and external stimuli or excessive sensitivity, a sense of mental emptiness or a sense of fullness, a disappearance of the subject-object discrepancy, imaginary dates appearing in total chaos or total concentration on internal experiences, total disintegration of internal life or its total integration, a sense of separating of what is physical from what is mental in a human being, a true experience of God's presence.

The analysis of related texts reveals that ecstasy often occurs during public religious rituals and is usually connected with the state of over-stimulation. It is the opposite of sensory deprivation through fasting, breath control, limited stimulation from the environment, and/or sleep deprivation [5,57]. A constantly increasing stimulation during group religious rituals and a portion of proper contents are a breeding ground for evoking emotional excitement in a bigger group of people. The most widespread phenomenon in this field is ecstatic dance, which has a mimetic background [64]. It is a kind of initiation instructions, sacrifice instructions. It has two basic tasks: (1) magical refers to a person's influence on Sacrum, and (2) theophoric refers to the dancer's imitating Sacrum. The vast variety and common occurrence of ecstatic dance in religious life proves its considerable importance in appearance of religious experience and related religious phenomena. A direct consequence of the exhausting dance is evoked ecstatic trance, which reaches its climax often in the form of physical exhaustion and "a state of deep sleep" [65].

\subsection{Mystical Rapture}

A given person's being oriented to the extra-sensory reality, divinity, and their radical re-orientation in the sphere of values, sometimes consisting in their depreciation of material goods, which is revealed in their acetic lives, often lead to an unusual experience, the so-called mystical rapture [5,52]. St Paul's and many other researchers' being caught up (2 Kor 12,1-5) is considered to be the preliminary state of a sudden process of religious life, taking an individual away from the natural state of sensations, and bringing them into a beyond-natural or even supernatural state of feelings and reactions. Namely, it turns out that during religious experiences, in the final phase of ridding of all possessed concepts, images of God (clearance phases, "dark night") [61], a human being is accompanied by states of elation, mystical raptures, which propel their mental-spiritual lives: "mystical elation, it is not just any flush of spirit or any ecstasy, during which the spirit seems to consciously choose isolation and concentrates there and gets rid of sensory activities; it happens only when the spirit violently, 
suddenly, and with its whole strength tears itself away from the sensory activities and hovers to the summit of contemplation and love of Divine things" ([17], p. 170).

The analysis of this phenomenon suggests that in the state of being mystically caught up, the soul rejects many external things up to the point of losing the use of senses, wanting only to live no other way than with God [49,54]. The religious phenomenon of mystical rapture is usually accompanied by features, like elation, joy of renewal, delight, exaltation, positive emotionalism, a need of preserving the pleasant feelings, and engagement. Human activism, however, is revealed in various acts of mercy, establishing monasteries, reforming churches, martyr deaths, and occasionally in extreme patriotic attitudes, selfless and diverse community activity [49,58].

\subsection{Glossolalia}

Glossolalia means speaking a language that is unknown or incomprehensible even to the person speaking it [66]. St Paul in his letters to religious communities mentions that the ability to speak various languages and translate them, which intertwine and complete each other, should be considered as a spiritual gift. St Paul connects glossolalia with the Holy Spirit (1 Cor 12:1-11). Glossolalia is a sign and consequence of the presence of the Holy Spirit in human life. The sender of the message about having met God and being sent by Him is a person who makes an impression on his or her listeners (1 Cor 14:1-26). The speaker is perceived as God's instrument and God himself is considered to be the true sender [67].

Nowadays glossolalia is especially revealed in charismatic movements emerging from the Pentecostal tradition. The tradition was started in 1901 by the Protestant preacher Charles Parham and has spread worldwide, adopting in the Catholic Church a form of Renewal in the Holy Spirit. An important characteristic feature of the prayer meetings of charismatic movements is spontaneity in expressing feelings and a lively and strong religious experience, which enhances the revealing of the phenomenon of conversion [68]. A form of spontaneous prayer, which simultaneously is the prayer of all participants of a prayer meeting [69], during which glossolalia frequently appears, inspired prayer (loud, longer prayer by one person), litany-like prayer (several people say their prayers of praise and thanksgiving to God and all respond "Glory to You, O Lord" or "We thank You, Jesus"), explanation of the Bible being inspired by the Holy Spirit, intercessory prayer (prayer with laying the hands on the head of the one who is praying for intercession, rituals of healing the sick, exorcisms, baptism in the Spirit) and giving witness (talking aloud in the group about one's own experience of God's activity) are the framework of speaking in tongues [70].

Glossolalia, which means a gift of speaking in tongues, is an expression of prayer states in a language unknown to oneself or the surroundings [68]. The gift can be revealed in forms of "meaningless singing", which consists in worshipping God without paying attention to the words or melody (all sing simultaneously but each sings something else) or in the form of solitary speaking in tongues, whose message is interpreted by another, inspired person. Transcultural studies have shown that this phenomenon occurs in various parts of the world [5]. It turned out that the sounds are spoken to a large extent in one's mother tongue, but also certain exotic sounds appear which cannot be found in the mother tongue [70]: "Patterns according to which sounds and accented syllables are connected show deviations from the mother tongue. Consistently glossolalia seem at first glance different from 
the mother tongue. Also diglossic words can be found, meaning combinations of sounds typical of glossolalia of different people. Therefore, in a sense, one can speak about the glossolalic tradition among the Pentecostals. On the other hand, a certain stereotype is marked possessed by a given person occurring in their various glossolalic statements." ([5], pp. 121-22).

\subsection{Stigmata}

Stigmata are external body marks similar to the wounds inflicted on Jesus Christ during his suffering (and crucifixion). They are perceived as the most known phenomena of the somatic order [52,71]. Authentic stigmata, unlike the forged ones, do not heal, remain fresh and uninfected. No decay of the body tissue has been observed in cases of stigmata, occasionally a specific odor is given out. A stigmatic feels a real physical pain adequate to the degree of the inflicted wound. Until recently scientists were mistrustful in their approach to some phenomena accompanying religious experience, including stigmata [72]. The incoming information about such cases were treated as unbelievable gossip or myths, accounts and reports about incredible achievements of yogis. The phenomenon of stigmata can be considered within psychosomatics where a psychosomatic disorder is interpreted as a symbol of expression of an organ, reflecting deep tendencies enrooted in human personality and is caused by an increase in the state of normal and physiological expression of emotions. Stigmata are related to an authentic mystical life, and despite the suffering they are a source of joy springing from a person's being unified with the suffering Christ [73].

Among the phenomena related to religious experience of physical dimension stigmata are the most conspicuous sign of the human soul's love of God and the Lord's love of man; they are God's embrace, who in a human being leaves a sign of His beloved Son's suffering [74]. It is an ineffaceable sign, present on the body, impressed by God on His chosen ones and indicating their belonging to Christ. Stigmata are the marks of Christ impressed - thanks to God's intervention — on the feet, hands and the side of people in which God's holiness is revealed. The marks can be visible or not, can be temporary or permanent. They differ as to their number, size and the body parts on which they appear. In some stigmatics they are visible all their lives, whereas in others they appear only on certain days or near special church holidays. They often have a form of visible bleeding wounds appearing on the body parts corresponding to the crucifixion wounds of Jesus [5,73].

The explanation of the origin of stigmata undertaken by Catholic scientists points to two different causes [71]. One group of researchers into this phenomenon claims that stigmata are a manifestation and effect of a human being's internal and supernatural dialogue with God personified. God would be a secondary cause, presenting the soul with infused contemplative grace of Jesus Christ's suffering. The contemplation of Jesus's suffering would be a source of a psychophysical process, which reconstructs the signs intensively contemplated by man. Other researchers suggest that stigmata are impressed as a result of God's miraculous and direct intervention in order to make a mystic's body similar to the image of the crucified Christ. As can be seen, for both groups, stigmata indicate God's special love, which by acting directly or indirectly through infused contemplation reveals and expresses his love of the chosen person [52,75].

During states of religious experience synthetization takes place, which is selective filtering of sensory stimuli in the human long-term memory. It happens in two ways $[5,76]$. The first one- 
through a person's culturally and socially determined preparatory set — and it refers to their knowledge, values, expectations, and defense mechanisms. The second way takes place during the process of learning, and refers to social and religious patterns and expectations. In this combination it can be expected that the gratifications of religious synthetization received during experiences of crisis enable man's euphoric experiencing of painful experiences linked with the perception of the world. According to researchers, the main role here plays religious tradition and modeling [19,77]. "Painful ecstasy is participation in Christ's suffering from the Mount of Olives till his crucifixion. In some ecstatics appear wounds similar to the wounds of the Crucified. This kind of ecstasy is accompanied by pain, which has a meaning of sacrifice for the person undergoing painful ecstasy. A person in painful ecstasy 'goes deeper into the thicket', till the embrace of death. The Mystical Doctor writes: These divine touches, so much sweetness and pleasure for the soul that one of them is enough to reward all, even countless pains it has to endure in life. It also becomes stronger and gains such courage to suffer a lot for God that it is a special suffering for it to see that it does not suffer much" ([17], pp. 162-63).

\section{Summing-Up}

The analysis of the spiritual lives of remarkable religious figures indicates that a human being's spiritual development takes place in specific phases, from purgation, through enlightenment, to the soul's unification with God. Sometimes this process is accompanied (as described in this paper) by such supernatural religious phenomena as visions, mystical ecstasy, mystical rapture, glossolalia, ecstasy, stigmata, which frequently took place in the lives of the early Christians and Saint mystics.

Christians - which emerges from their vocation - participate in Jesus Christ's salvation within the Church. They learn directly the Good Tiding that Jesus Christ died for them and rose from the dead, they experience new life, which He brings by His presence in His church, they are also called to give testimony. Being a witness is realized in many ways. God calls on particular people in the appropriate moment, presents them with specific gifts to serve the goal (gift of prophecy). They also include certain religious phenomena (ecstasy, stigmata), which are from the healing and redeeming God, perceived as signs, which prompt and encourage believers to greater love of God and fellowmen.

It must be said that religious phenomena point to God's love and His incessant love of mankind, which in order to remind people, for example of Christ's suffering, is engraved in the hearts of chosen individuals by continuous shaping them following the example of the Crucified one; moreover, it left marks on their bodies to be permanently remembered. A person experiencing them remembers the mystery of God's economy of salvation, Christ's act of saving in which he allows the chosen ones to suffer again, and contributes to the spreading of the Kingdom of God, directing and sending away the lost ones through the present signs of suffering to wisdom and love of the Cross.

The analysis of religious phenomena reveals that mystics, when attempting to describe their religious experience and related religious phenomena, encounter insurmountable difficulties. They often cannot find proper words to depict fully the state and contents of their experiences. However, they claim that their ecstatic religious experiences were the source of vitality in their lives and success in accomplishing acts of kindness, especially acts of mercy. These phenomena stimulate imagination and arouse feelings in people who are experiencing them and in those who are in contact with them, 
and which are inexpressible in words. They connect intellectual intuition with an emotional reaction. Similarly to poetry, they depict a certain interpretation of the spiritual-mental reality of a human being.

The religious lives of mystics indicate the need of religious phenomena in a human being's individual life and their community life in the church. As mystics suggest, the phenomena can delight a doubting person, make available to them the depth of knowledge and understanding, strengthen their faith. They are gifts from God for the good of all believers. Simultaneously, lack of these phenomena in human spiritual life does not indicate an absence of development of spiritual life and a person's shutting down to the influence of the Holy Trinity in his or her soul, because they are important but do not comprise in any way the essence of a human being's spiritual life.

The analysis of religious phenomena suggests that people who experience them gain a new quality of life; they are a special sign of God's activity. For a given community religious phenomena become a sign of Transcendence, because it is a certain revelation of God, and they are also an authority in its broad meaning. They can influence not only the religious dimension of the members of a given community, but also non-religious aspects, for example in widely understood education.

\section{Conclusions}

The analysis of supernatural religious phenomena occurring in the lives of believers allows one to draw several conclusions.

There is an increasing occurrence of the phenomena of religious experience in people's lives within the Church community and outside it. Several researches have shown that $[5,19,40]$. Therefore, there is a need for proper reflections on this issue, which requires a consideration of the entirety of Christian life of people who experience these phenomena.

Religious experience and the accompanying religious phenomena can be understood as a significant component of self-realization and spiritual-mental maturity of a human being. Both blissful and painful ecstasies, mystical raptures, are the moments in human life after which comes an extraordinary increase in strength and activity, regeneration of the whole body, as if contrary to the theories claiming their pathological origin.

Preparing an objective assessment of religious phenomena requires profound scientific studies and religious maturity. It is important that the approach to this type of phenomena have an integral character. The whole person ought to be considered while assessing them, together with their mental-spiritual state and cultural conditions.

When assessing religious phenomena one must realize that similar spiritual phenomena can be caused by Satan or originate naturally, mainly through autosuggestion or hypnosis. Their source may be in a disturbed personality or they can be caused by psychedelic substances. They are not always signs of God's interventions or the result of a process of spiritual development of the individual. Moreover, similar symptoms may be accompanied by the phenomena caused by the action of God by psychedelic substances.

It seems that the problem discussed in this article is very important and up-to-date, in the light of a visible interest in our culture in religious experience and sometimes accompanying supernatural religious phenomena. The present analysis of this issue shows considerable significance of religious 
phenomena in human spiritual life and the church, and is an invitation to some broader reflections of theological-psychological nature and further studies in this field.

\section{Conflicts of Interest}

The author declares no conflict of interest.

\section{References and Notes}

1. Josef von Sudbrack. Mystik. Selbsterfahrung-Kosmische Erfahrung-Gotteserfahrung. Mainz: Matthias Grünewald Verlag, 1988, pp. 113-57.

2. Ann Taves. Fits. Trances and Visions: Experiencing Religion and Explaining Experience from Wesley to James. Princeton: Princeton University Press, 1999.

3. Micheal A. Thaibourne, and Peter S. Delin. "Transliminality: Its Relation to Dream Life, Religiosity and Mystical Experience." International Journal for the Psychology of Religion 1 (1999): 45-61.

4. Werner D. Gruehn. Die Frömmigkeit der Gegenwart.: Grundtatsachen der Empirischen Psychologie. Münster: Aschendorffsche Verlagsbuchhandlung, 1956, pp. 441-76.

5. Stanisław Kuczkowski. Psychologia Religii (Psychology of Religion). Kraków: Wydawnictwo WAM, 1998, pp. 110-42.

6. Roman Jaworski. Harmonia i Konflikty (Harmony and Conflict). Warszawa: Wydawnictwo UKSW, 2004, pp. 220-23.

7. Janusz Mariański. Katolicyzm Polski. Ciagłość i Zmiana. Studium Socjologiczne (Polish Catholicism. Continuity and Change. Sociological Study). Kraków: Wydawnictwo WAM, 2011.

8. Walter H. Clark. Chemical Ecstasy. Psychedelic Drugs and Religion. New York: Sheed and Ward, 1969.

9. Stanislav Grof. Realms of the Human Unconscious, Observations from LSD Research. London: Souvenir Press, 1993.

10. Andrew B. Newberg. Principles of Neurotheolgy. New York: Ashgate, 2010.

11. Micheal A. Thalbourne, and Peter S. Delin. "A Common Thread Underlying Belief in the Paranormal, Creative Personality, Mystical Experience and Psychopathology." Journal of Parapsychology 59 (1994): 3-38.

12. Stanislav Grof. Beyond the Brain: Birth, Death, and Transcendence in Psychotherapy. Albany: State University of New York Press, 1985.

13. Greg N. Byrom. "Differential Relationships between Experiential and Interpretive Dimensions of Mysticism and Schizotypal Magical Ideation in a University Sample." Archive for Psychology of Religion 31 (2009): 127-50.

14. William A. Richards. "The Phenomenology and Potential Religious Import of States of Consciousness Facilitator by Psilocybin.” Archive for Psychology of Religion 30 (2008): 189-99.

15. Marghanita Laski. Ecstasy: A Stady of Some Secular and Religious Experiences. Bloomington: University of Indian Press, 1961.

16. Steven T. Katz. "Language, epistemology and mysticism." In Mysticism and Philosophical Analysis. Edited by Steven T. Katz. Oxford: Oxford University Press, 1978, pp. 22-74. 
17. Antoni J. Nowak. Identyfikacja Postaw (Identification of the Attitudes). Lublin: Wydawnictwo KUL, 2000, pp. 141-74.

18. Austin Flannery. Dogmatic Constitution on the Church, Vatican Council II: Constitutions, Decrees, Declarations (Vatican Council II). New York: Costello, 1996.

19. Stanisław Radoń, and Stanisław Głaz. Przeżycia Religijne Młodzieży Uzdolnionej Artystycznie (Religious Experiences of Artistically Gifted Youth). Kraków: Wydawnictwo WAM, 2006, pp. 57-73.

20. David Basinger. Religion Diversity. A philosophical Assessment. New York: Ashagate, 2002, pp. 11-55.

21. Willian P. Alston. "Mysticism and Perceptual Awareness of God." In Philosophy of Religion. Edited by William Mann. New York: Blackwell Publishing, 2005, pp. 123-40.

22. William James. L'Expérience Religieuse. Essai de Psychologie Descriptive. Paris: Felix Alcan, 1908, pp. 324-63.

23. Rudolf Otto. Le sacre: L'élément Non-Rationnel dans L'idée du Divin et sa Relation avec le Rationnel. Paris: Payot, 1968, pp. 15-150.

24. Johan Unger. On Religious Experience. Uppsala: Acta Universitas Uppsaliensis, 1976.

25. Carl G. Jung. Esperienza e Mistero. Torino: Boringhieri, 1982, pp. 26-30.

26. Erich S. Fromm. Psychoanalyse und Religion. Zurich: Wilhelm Goldmann Verl, 1966.

27. Beverly J. McCallister. "Cognitive theory and religious experience." In Handbook of Religious Experience. Edited by Ralph W. Hood. Birmingham: Religious Education Press, 1995, pp. 312-52.

28. Dariusz Krok. "Structural Relations between Religiosity and Spirituality in the Context of Personality Factors." In Personality and Religion. Edited by Henryk Gasiul, and Elżbieta Wrocławska-Warchala. Warsaw: Wydawnictwo UKSW, 2009, pp. 280-99.

29. Sigmund Freud. A Religious Experience, standard ed. London: Hogarth Press, 1928, vol. 21, pp. 167-72.

30. Sigmund Freud. Introduction à la Psychanalyse. Paris: Payot, 1951.

31. Leonardo Ancona. "S. Maria Maddalena de Pazzi alla luce della psicologia." Carmelus 13 (1966): 3-20.

32. Jerzy W. Gogola. Mistycy i Mistyka Karmelu (Mystics and Mysticism of Carmel). Kraków: Wydawnictwo Karmelitów Bosych, 2007, pp. 17-117.

33. Peter C. Hill. "Affective Theory and Religious Experience.” In Handbook of Religious Experience. Edited by Ralph W. Hood. Birmingham: Religious Education Press, 1995, pp. 353-77.

34. Wilhelm Breuning. "Esperienza." In Lessico di Teologia Sistematica. Edited by Wolfgang Beinert. Brescia: Queriniana, 1990, pp. 270-72.

35. Zofia J. Zdybicka. Człowiek i Religia (Man and Religion). Lublin: Wydawnictwo KUL, 1977, pp. 270-72.

36. Gordon W. Allport. The Individual and His Religion. New York: Macmillan, 1950, pp. 1-30.

37. Zdzisław Chlewiński. "Religia a osobowość człowieka (Religion and Human Personality)." In Religia w Świecie Wspótczesnym (Religion in the Modern World). Edited by Henryk Zimoń. Lublin: Wydawnictwo KUL, 2000, vol. 1, pp. 89-128.

38. Czesław Walesa. Rozwój Religijności Człowieka (The Development of Human Religiosity). Lublin: Wydawnictwo KUL, 2005, pp. 13-27. 
39. Walter H. Clark, Newton H. Malony, James Daane, and Alan R. Tippett. Religious Experience: Its Nature and Function in the Human Psyche. Illinois: Thomas Springfield, 1973.

40. Stanisław Głaz. Doświadczenie Religijne (Religious Experience). Kraków: Wydawnictwo WAM, 1998, pp. 211-64.

41. Jean Danielou. L'avenir de la Religion. Paris: Fayard, 1969, pp. 41-73.

42. Thomas Keating. Intimacy with God. New York: Crossroad Book, 2001.

43. "La vita 'cristiana' dell'unione con Dio." La Civilta Cattolica 3354 (1990): 521-32.

44. Karl Rahner. Corso Fundamentale Sulla Fede. Introduzione al Concetto di Cristianesimo. Torino: Edicioni Paoline, 1984, pp. 161-88.

45. Kazimierz Popielski. Psychologia Egzystencji (Psychology of Existence). Lublin: Wydawnictwo KUL, 2008, pp. 30-42.

46. Max Scheler. Essenza e Forme Della Simpatia. Roma: Citta Nuova Editrice, 1980, pp. 49-224.

47. Marek Jarosz. Interpersonalne Uwarunkowania Religijności (Interpersonal Considerations of Religion). Lublin: Wydawnictwo TN KUL, 2003, pp. 13-45.

48. Wojciech Misztal. "Kierownictwo duchowe wobec nadzwyczajnych fenomenów mistycznych (Spiritual Direction to the Extraordinary Mystical Phenomena)." In Zjawiska Nadzwyczajne a Świętość (Extraordinary Phenomena and Holiness). Edited by Jerzy W. Gogola. Kraków: Karmelitański Instytut Duchowości, Wydawnictwo Karmelitów Bosych, 2010, pp. 145-69.

49. Ermanno Ancilli. "Le visioni e la rivelazioni." In La Mistica: Fenomenologia e Riflessione Teologica. Edited by Maurizio Paparazzi and Ermanno Ancilli. Roma: Citta Nuova, 1984, pp. 473-81.

50. Józef Ratzinger. “Komentarz Teologiczny” (“Theological Commentary”). L'Osservatore Romano 9 (2000): 47-51.

51. Gaetano Benedetti. Psychotherapy in Schizophrenia. New York: New York University Press, 1987.

52. Camillo Becattini. "Esperienza Mistica e Fenomeni Mistici: Linee di Interpretazione Psicologica." In La Mistica: Fenomenologia e Riflessione Teologica. Edited by Ermanno Ancilli and Maurizio Paparozzi. Roma: Citta Nuova, 1984, vol. 2, pp. 387-447.

53. Felicitas Goodman. Ecstasy, Ritual and Alternate Reality: Religion in a Pluralistic World. Bloomington: Indiana University Press, 1988.

54. Jerzy W. Gogola. "Ekstaza (Ecstasy).” Leksykon Duchowości Katolickiej (Encyclopedia of Catholic Spirituality). Edited by Marek Chmielewski. Lublin-Kraków: Wydawnictwo M, 2002, pp. 2453-54.

55. Katarzyna Krzan. Ekstaza w Wersji pop (Ecstasy Pop Version). Warszawa: Wydawnictwo Naukowe i Profesjonalne, 2008, pp. 30-170.

56. Ignatius Loyola. The Spiritual Exercises of Saint Ignatius. St. Louis: The Institute of Jesuit Sources, 1992.

57. David Wulff. "Phenomenological psychology and religious experience." In Handbook of Religious Experience. Edited by Ralph W. Hood. Birmingham: Religious Education Press, 1995, pp. 183-99.

58. Massimo Baldini. "Il silenzio mistico e la finitezza della parola." Rivista di Ascetica e Mistica 2-3 (1986): 137-45.

59. Francesco Asti. Dalla Spiritualità alla Mistica. Città del Vaticano: Libreria Editrice Vaticana, 2005. 
60. William Meissner. Ignatius of Loyola: The Psychology of a Saint. New Haven and London: Yale University Press, 1992.

61. Saint Jean de la Croix. La Montée du Carmel. Lille: Desclée de Brouwer, 1925, vol. 3, pp. XIV-XV.

62. Harvey Egan. I Mistici e la Mistica. Antologia Della Mistica Cristiana. Città del Vaticano: Libreria Editrice Vaticana, 1995.

63. Zenomena Płużek. "Psychologiczna analiza Doświadczenia Religijnego (Psychological Analysis of Religious Experience).” In Mistyka w Życiu Czlowieka (Mysticism in Human Life). Edited by Waldemar Słomka. Lublin: Wydawnictwo KUL, 1980, pp. 93-109.

64. Erika Bourguignon. Trance Dance. New York: Dance Perspectives Foundation, 1968.

65. Judith L. Hanna. "The Representation and Reality of Divinity in Dance." Journal of the American Academy of Religion 66 (1988): 281-306.

66. Felicitas D. Goodman. Speaking in Tongues: A Cross-Cultural Study of Glossolalia. Chicago: University of Chicago Press, 1972.

67. Nils G. Holm. "Writing Heavenly Language': My Research on Pentecostalism and Glossolalia." In Psychology of Religion. Autobiographical Accounts. Edited by J. Belzen. Amsterdam: University of Amsterdam, 2012, pp. 91-106.

68. Willian J. Samarin. “Language in Resocialization.” Practice Anthropology 17 (1970): 269-79.

69. John Kildahl. The Psychology of Speaking in Tongues. New York: Harper \& Row, 1972.

70. Nils G. Holm. "Function of glossolalia in the Pentecostal movement." In Psychological Studies on Religious Man. Edited by Thorvald Kallstad. Stockholm: Almqvist \& Wiksell, 1978, pp. 141-58.

71. Czesław Ryszka. Stygmatycy (Stigmatics), 3rd ed. Bytom: Oficyna Wydawnictwa 4K, 1998, pp. 252-58.

72. Marino Barfucci. "Stygmaty św. Franciszka (Stigmata of St. Francis)." In Leksykon Duchowości Franciszkańskiej (Lexicon Franciscan Spirituality). Edited by Wacław Michalczyk. Kraków-Warszawa: Wydawnictwo M, 2006, pp. 1725-38.

73. Gaudens E. Mohan. "Petrus Thomae on the Stigmata of St. Francis." Franciscan Studies 8 (1948): 285-94.

74. Carty Charles Mortimer. Padre Pio le Stigmatisé. Paris: La Colombe, 1957, pp. 23-41.

75. Michael Freze. They Bore the Wounds of Christ: The Mystery of the Sacred Stigmata. Our Sunday Visitor, 1989.

76. Augustin Poulain. "Mystical Stigmata." In The Catholic Encyclopedia. New York: Robert Appleton Company, 1912, vol. 14. Available online: http://www.newadvent.org/cathen/14294b. htm (accessed on 4 December 2014).

77. Karl E. Schmoeger. Vie d'Anne Katherine Emmerich. Paris: Bray et Retaux, 1968, pp. 260-75.

(C) 2014 by the author; licensee MDPI, Basel, Switzerland. This article is an open access article distributed under the terms and conditions of the Creative Commons Attribution license (http://creativecommons.org/licenses/by/4.0/). 